\title{
The Woman Artist in Edna St. Vincent Millay's Poetry 1
}

My candle burn at both ends;

It will not last the night;

But ah, my foes, and oh, my friends -

It gives a lovely light!

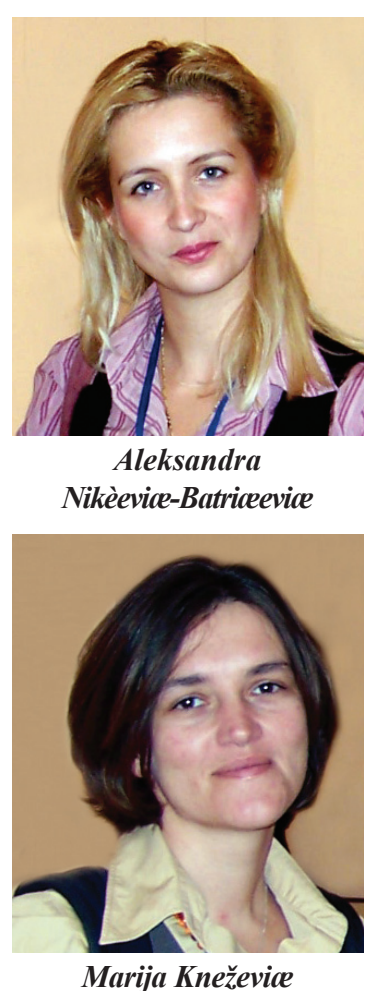

T egendary figure, a woman of spirit and independence, the first one to receive a Pulitzer prize for literature, Edna St. Vincent Millay built her poetics by reacting to and confronting the complex issues that has been concerning us forever, "relationship between men and women, compassion for one's fellows, commitment to one's country, the tender stewardship of our natural resources" (Epstein 2001:156). She transformed those issues into the highly lyrical material, into the poetry of enduring value, molding her poems in a sensational and, sometimes, a highly provocative manner, while insisting on the dynamic vision of reality and showing how every poem of hers is "a work in progress or in process, subject to complex of forces that were, for Wimsatt and Beardsley, discernibly either 'internal or external' to the literary object" (Becker-Leckrone 2005:12). From the famous twenties in the past century until now, Millay has remained both fascinating and repulsive for her readers, throwing them "into unsettling states in which the boundaries of life and death, the stability of meaning, seem constantly threatened" (41). Daniel Mark Epstein, one of her biographers, in his book What Lips My Lips Have Kissed: The Loves and Love Poems of Edna St. Vincent Millay, writes that the woman artist in her poetry rebelled against cliche, cant, rhetoric, and superficial sentimentality, and that it is through the fierce treatment of the traditional forms that she performed her rebellion: she revolutionized the poetic form by making it more impressionable of the unstable emotions and chaotic perceptions of the twentieth century.

In the Oxford Companion to American Literature, in an entry about Millay, she is described as a poet "who exhibited technical virtuosity, startling freshness, and a hunger for beauty" (Hart 1995:432). Later in her career, especially in a collection of poems titled A Few Figs from Thisles, "she showed that though the disillusion of the postwar years 
was crowding in upon her, she was attempting to maintain gaiety with a consciously cynical flippancy" (432). In one of the collections that followed, The Harp-Weaver and the Other Poems, Hart writes that she is noted for poems showing a further deepening from her earlier arch attitude to a more disillusioned bitterness, as well as for mature technical ability, particularly in the sonnet, the form in which her lyric gift, and her directness were exhibited.

But, let us for the moment stop in order to avoid imposing an alien perspective on her poetry, although the critics repeatedly remind us that Millay must be read in light of her own assumptions, that "the exclusions and necessities she endured, and, therefore her choices, were conditioned by her own world" (Becker-Leckrone 46), and most explicitely characterized by the central rhetoric device in most of her poems, and that is the use of the personal voice, informed by its own perspective and perceptive in approach to her own poetry. According to Epstein, the most remarkable fact in her writing of the period when "The First Fig" was published, is the power and enthusiasm of her expression in which there were no traces of "artificial rhetoricism. The fine lyric quality of her verses was allowed to stand forth unobscured by posing and affectuation" (Epstein 2001:185). It is well known how the poem affected her career. Nancy Milford writes that the general reading public was stunned: the poem has usually been demarcated as witty, flippant, defiant, and fun. The change that occurred within the critical perception of her work is stunning itself and although the other scholars might suggest a myriad of alternative approaches to this poem, it might be understood as coding one moment of crisis as according to Julia Kristeva, whose theoretical postulates in reference to this poem by Millay we shall discuss later, the moment of crisis might be defined not as an ultimate resistance, but as an unveiling of the abject.

The fact that "The First Fig" is basic in understanding of Millay's poetics, essential in formation of the subject, providing a brief but essential account of its formation, cannot be challenged. In fact, the single stanza, what Norma Millay in her sister's published latters called "the candle one, surely the most quoated and misquoted quatrain in America" (160), became the hymn of her generation: "Here was a quatrain that people, young women especially, took to heart. They took it even further; the Jazz babes, as they soon will be called, took it as their rallying cry" (160).

Some critics suggest that 'The First Fig' expresses an ideal of Latin poets Millay knew and loved, implying thus " a complicated, 'the heterogeneous practice' that puts old texts in dialogue with new and involves the reader as well as the 'writing subject,' a subject shaped jointly by the forces of history, ideology, the unconscious, and the body," (Becker-Leckrone 13) in a sense of Bakhtin's thesis that the text is plural, although Millay herself repelled 'the saturation of old discourses,' implying that the thematic coherence of this poem with those from the Latin tradition, remains undefiable:

'Life is impermanent and in the face of that impermanence, cavort! Look death in the eye, tell him you're as cute as a button, flash a little, defiant guile his way, and tell him to go fast on somebody's else's sweet flesh'. (Epstein 160) 
The subtle performance of woman artists in Millay's poetry is mediated by class, nationality, sexual orientation, historical era, literary movements and theories of language, influences that Kristeva deems important, as well as through the clash between the context and the poet's imaginative constructs. "The First Fig" registers the climax of those influences: as opposites that correlate in the poem they combat with each other, energizing thus the thematical, stylistic and rhytmical concerns in her poetry. The poem further might be defined as being about 'revealing, examining and criticizing, the possibilities'; it reclames, articulates, and amplifies the modernistic expression of woman's point of view, the celebration of the survival of this point of view in spite of the challenging forces that have been raging against it. It presents, more concretely, recovery and cultivation of female voice. The character of the author, "the substantial, palpable presence animating her works" (Becker-Lecrone 38), is divided subconsciously into two protagonsists featured in this poem: the woman poet and the woman reader. The woman poet is standing as a symbol of cultural and political dimension; the second is dialogic. They are engaged in intimate conversation, while the poem stands as a symbol of a female paradigm or, according to Kristeva, intersubjective construction of the relationship. The reader encounters not simply a text, but a "subjectified object: the heart and mind of another woman" (39). If we accept the thesis by Kristeva it seems that Millay is closely introspecting anothers interiority - a power, a creativity, a suffering, a vision - that is similar to her own:

"A book is not only a book; it is a means by which an author actually preserves [her] ideas, [her] feelings, [her] modes of dreaming and living. It is a means of saving [her] identity from death... To understand literary work, then, is to let the individual who wrote it reveal [herself] to us in us." (439)

But, why Millay and Kristeva? Because both of them tend to bring the body back: Millay into poetic discourse, Kristeva into human sciences. Furthermore, the reason for making the pregnant inroads into Kristeva's key concepts in the analysis of this poem, is because both of them focus on the significance of the maternal and preoedipal in the constitution of subjectivity (Kristeva's notion of abjection as an explanation for oppression and discrimination can easily be detected in the text of this poem by Millay)2; Millay and Kristeva because of the fact that we have to take into consideration the importance of the context in which Millay lived and worked, especially the twenties when she published her most famous poems, at "a historical moment that seems on the verge of upheavals at once linguistic, aesthetic, political, and intellectual" (11). The poem, accordingly conveys two possibilities: "the most intimate discourse of the self to the most collective discourse of mankind (religious, political, and so on.)" (19).

1. in reference to the concept of abjection this poem might be defined as the radical presentation of the speaking subject, of the crisis that subject experiences, in a sense that this poem is a mode of expressing those horrors, instead of repressing them. 
The horror is provoked by the 'profound upheaval of mentalities' in the US at the beginning of the century. It presents the paradigmatic instance, the culmination of discompossing horrors that poet faces at one moment in her life. To paraphrase Kristeva, in this poem Millay shows "extraodinary ability to absorb digest, and neutralize all of the key, radical or dramatic moments of thought" (23); the triad of "horror, love and melancholic ambiguity' present radical manifestations of extreme subjective crisis, Kristeva writes. The poem might also be understood as a mask of dissatisfaction with the anticipated image of a female writer, a moment of culmination of pre-Oedipal, 'specular' relation between an ideal-I, and an actual I. According to Lacan, this moment in her poetry might implicate the condition, "by which the subject will relate to objects, distinguish self from other, in the realm of symbolic" (28) as if taking a journey of a solitary soul (reference to Kate Chopin!), or, as Kristeva wrote in her analyzes of Celine's Journey to the End of the Night, the poem is like a trope of "a journey, during the night, the end of which keeps receding" (32). The abjection draws the subject to the limits of its own demarcated boundaries. The crisis of place in America is characterized by chaos and din, and, according to Kristeva, it precipitates a crisis of meaning and identification ("What is that? Is that me? What I am? How have I changed?") (8) in a sense that by this poem both the subject and the author, are summoned from their proper place to a no-man's land where the subject is not only "beside himself but also almost ceases to be" (33) (when regarded in reference to the context to which she belongs), the no-man land where the abject crisis is mostly evident, as she recalls "infantile pangs of separation or threaten 'death infecting life" " (37) from the presentations and behavioral concepts that were required of her. Millay's model of abjection might further be defined as "cultural taboos regarding the maternal" (38). In her poetry the crisis of context is the crisis of subject, as it seems that in this poem Millay sums up the personal experience and her direct account of the era.

2. according to another key concept of Kristeva, agape/eros concept, Millay is a prototype of a New Woman, whose premise is the established image of free love, while the various and specific dynamics affect the amorous protagonists who are revealed out of it. Kristeva argues that "the subject must arise in order to unify: the separation from the mother allows the subject to produce an ego, and this production expresses itself in terms of an ego ideal, which makes it possible for the subject to love," (152), to love her own independence, her own difference. In the light of this concept the subject that the author exemplifies might be defined as dionysian, while the word 'friends' indicates the existence of the carnival and carnivalesque to mean a general process of transgressing literary, political, or social norms (153), as we might add that the poem depicts the moment or "an occasion in which the normal order and hierarchies of society are, for a time and in a given place, temporarily suspended" (153). Millay, herself is carnivalesque in a sense that she challenges God and patriarchal constructs.

3. the concept of dialogizing, or, according to Kristeva the 'double-voicing' of American societal concept, according to which Millay is on the side of the necessity to 
decentralize, contrary to the tension to centralize that is inherent to the American societal concept. The concept of dialogizing might be considered in reference to relation to the poetic text from an older tradition, Latin in this case, what Kristeva has termed the 'interpenetration and interdependence'.

4. the concept of intertextuality in Millay's poem, that according to Kristeva stresses the passage from one sign system to another that takes place "as one text creates itself out of the thematic and generic materials of another text" (155), the moment in her opus when we can most easily notice 'the interpenetration and interdependence' of historical foreground that provides 'the very capacity for the meaning to exist'.

5. the interplay of semiotic and symbolic, so important in Kristeva's work, plays the important role in the understanding of this poem (162-165), in a sense that it presents double force or ground from which the poem apprises (162). The semiotic is provoked by a feminine heritage, the figure of mother being very important in Millay's development of ego, while the symbolic is provoked by the origins of the father, symbolically presented by the upheavals of mentalities in the US. Thematic changes in this part of Millay's career, constitute changes in the status of the subject (164).

Reading 'The First Fig' from the context of Kristeva's key concepts reveals the basic postulates that are existent within the whole corpus of Millay's poetry, although the gradual change in their expliciteness from one poem to another, from one collection to the next, is discernible. The reading through Kristeva provides the close interospection of two complex areas: the context and the text, revealing to us that the formation of the woman artist finds its culmination within this short poem.

\section{Notes:}

1. Do not consider our paper as hermetic or self-referential, because in it we were relying (by both quoting and paraphrasing) on the certain segments of study about Julia Kristeva and literary criticism, by Megan Becker-Leckrone, as well as Kristeva's study.

2. In this segment of the paper we paraphrased quotation on Kristeva by Oliver Kelly. See the bibliographical source below.

\section{References:}

1. Becker, Leckrone, Megan (2005) Julia Kristeva and Literary Theory. New York: Palgrave Macmillan.

2. Epstein, Daniel Mark (2001) What Lips My Lips Have Kissed: The Loves and Love Poems of Edna St. Vincent Millay. New York: Henry Holt and Company. 
3. Felluga, Dino. Modules on Kristeva: On the Abject // Introductory Guide to Critical Theory. http://www.purdue.edu/guidetotheory/psychoanalysis/kristevaabject.html, accessed at August 3, 2007.

4. Hart, James, D. (1995) The Oxford Companion to American Literature. New YorkOxford: Oxford University Press.

5. Kelly, Oliver: Kristeva and Feminism. http://www.cddc.vt.edu/feminism/Kristeva. html, accessed at August 18, 2007.

6. Kristeva, Julia (1982) Powers of Horror.New York: Columbia University Press.

7. Kristeva, Julia (1982) Poetic Language. New York: Columbia University Press.

8. Milford, Nancy (2001) Savage Beauty: The Life of Edna St. Vincent Millay. New York: Random House.

9. (1980) Desire in Language. / Ed. by Roudiez, Leon. New York: Columbia University Press.

\section{GhG mpltuunuqtinn tnam Uhıtjh untiqhujnıu}

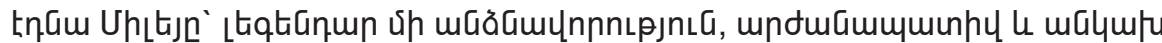

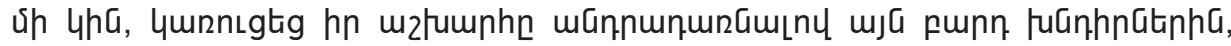

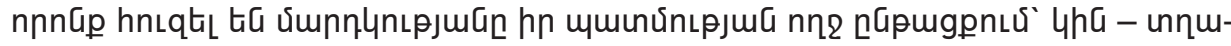

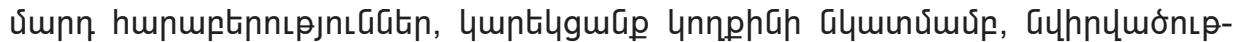

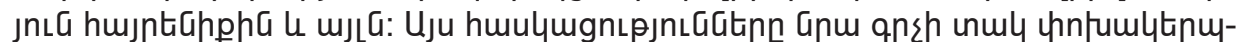

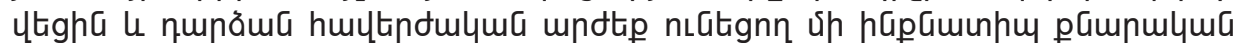

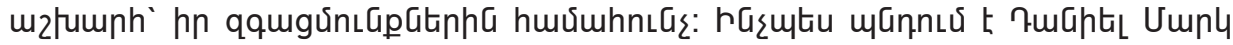

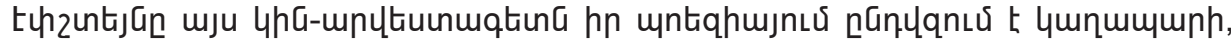

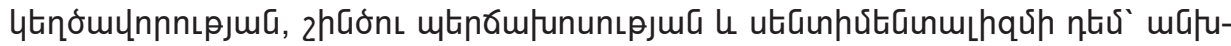

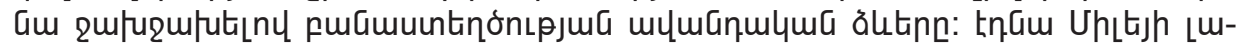

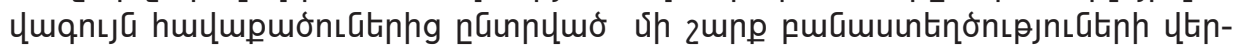

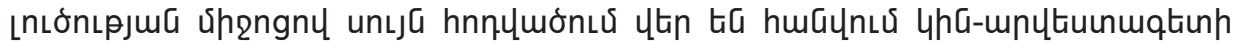

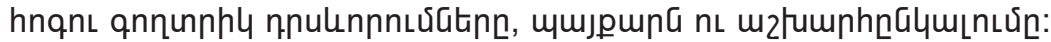

